\title{
焼結タングステン細線における インターロック組織の最適化
}

\author{
田上耕司 渡 邊 和 弘 $^{\dagger}$ 松田日出彦
}

九州工業大学工学部物質工学科

J. Japan Inst. Metals, Vol. 59, No. 12 (1995), pp. 1230-1236

\section{Optimization of the Interlocking Grain Structure in P/M Tungsten Fine Wires}

\author{
Koji Tanoue, Kazuhiro Watanabe and Hidehiko Matsuda \\ Department of Materials Science and Engineering, Faculty of Engineering, \\ Kyushu Institute of Technology, Kitakyushu
}

\begin{abstract}
The measurement of the three-dimensional shape of secondary recrystallized grains, and delamination, creep and tensile tests are made to clarify the optimum interlocking grain structure which fills such two opposing roles as the improvement of creep resistance and the prevention of grain boundary fracture in $\mathrm{P} / \mathrm{M}$ tungsten fine wires. Some parameters characteristic of the degree of interlocking among grains are derived and reliably reflect a distinctive change in the contours of grains which are three-dimensionally constructed. The effect of grain configuration to suppress creep rates with an increase in the degree of interlocking is detected in the structure which has a small area of grain boundary. However, the increase in creep rate is confirmed in the structure which has a large area of grain boundary because of an additional interlocking. On the other hand, the tensile strength increases monotonically at room temperature as the grains are interlocked. It is therefore possible to decide the optimum structure which realizes both high tensile strength and high creep resistance at the same time.

(Received March 8, 1995)
\end{abstract}

Keywords: interlocking, bubble, grain boundary character, grain boundary fracture, tensile strength, creep, doped wire, tungsten

\section{I. 緒言}

線林軸方向に列をなして点在するバブルは軸に直角な方向へ の粒成長を抑制し，その程度はバブルの分布の密度に比例する ことが報告されている(1)，その結果，2次再結晶粒は線材軸方 向に長く，かつ互いた入り組んだ(interlocking)組織となり， 全体として粒界面積を減少させるため粒界すべりや粒界キャビ テーションのよらな粒界の存在そのものに起因する高温クリー プを效果的に抑制する(2)(3).この效果は 2 次再結晶粒が単結 晶に近づく汇ど大きくなる、しかしながら，あまり長大な 2 次再結晶粒は幾何学的に入り組んだ組織を取りにくく,フィラ メントの消灯時発生するねじり応力に上りしばしば粒界破壞 を引き起こす。したがって，粒の形状は長大でかつ入り組んで いるといら相反する条件を適度に満足するものでなければなら ない。このように比較的強い共有結合性のために粒界が弱く, 加立て延性一脆性遷移温度が $250 〜 500 \mathrm{~K}$ Kあるた室温に和 いて粒界破壞しやすいタングステン細線ではインターロックし た2次再結晶粒を形成させ，一部の弱い粒界強度を補らこと

†州工業大学大学院生, 現在 : 広島アルミニウム工業(侏)
によって全体の強度を向上されてきた。しかし，インターロッ ク組織を利用した強度の向上はその定量的取り扱いがなされて いないために経験的手法に頼っているのが実状である。

そこで本研究においては，先ず2次再結晶粒のどのような 性格の粒界が破壊し易いかを明らかにする，そして，粒の3 次元的形状の測定からインターロックの程度を示すパラメータ 一を導出し, それと定常クリープ速度や引張破断強度との関係 を調ベる，それらの結果に基づき，耐クシープ性の向上と粒界 破填防止という相反する 2 つ役割を満足する最適なインタ 一ロック組織を明らがすることを目的とする。

\section{II. 実 験 方 法}

実駼に使用した試料は公称純度が $99.96 \%$ 以上の焼結純タン グステン細線 $(\phi 0.13 \mathrm{~mm})$ である。試料の熱処理はすべて $<10^{-4} \mathrm{~Pa}$ 真空中に括ける直流通電加熱方式に上って行っ た、インターロックの程度の異なる結晶粒を得るため, 昇温速 度を $0.2 \sim 880 \mathrm{~K} / \mathrm{s}$ の範囲内で变化させ $2273 \mathrm{~K}$ まで昇温し， 同温度で $300 \mathrm{~s}$ 間保持して完全 2 次再結晶化させた。 そして,

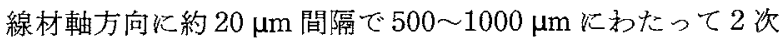
元的な結晶粒の形状を測定し，3次元画像解析装置(ニュン社 
製コスモゾーン)を用いて粒の立体像を組み立てた。この立体 像から粒の表面積 $S$ を測定して長さ約 500 1000 $\mu \mathrm{m}$ の試料 の体積 $V$ 中に存在する全粒界面積を単位体積当たりの粒界面 積 $S / V$ として求め, さらに各割断面 $i$ 亿必方粒の断面積 $A_{\mathrm{i}}$ 之周長 $P_{\mathrm{i}}$ から $A_{\mathrm{i}}$ と形状因子 $F_{\mathrm{i}}\left(=4 \pi A_{\mathrm{i}} / P_{\mathrm{i}}^{2}\right)$ を線材軸方向に 沿って求めた。ここで $F_{\mathrm{i}}$ は周長 $P_{\mathrm{i}}$ を持つ真円の面積 $A_{\mathrm{i}}^{\circ}$ 亿対 する $A_{\mathrm{i}}$ の割合 $A_{\mathrm{i}} / A_{\mathrm{i}}^{\circ}$ として求められるので， $F<1$ であり， $F$ が 1 に近つくにつれて真円炕近くなる，得られた $A$ と Fが軸 万向いどのように変化するかを調べてインターロックの程度を 示すパラメーターを導出した。 をたすすへてて精の方位をエッ チピット法で決定した。粒界性格の測定に適した大きさまで粒 が粗大化する $0.4 \mathrm{~K} / \mathrm{s}$ で昇温させ $2273 \mathrm{~K} て ゙$ 焼鈍した陚料につ いては液体窒素中で線材軸に直角な力向に単位長さ当たり 75 $\mathrm{N} / \mathrm{mm}$ の荷重をかけて一部の粒界を圧縮剝離破断させた。こ の荷重は全粒界の約 $60 \%$ が破壊するような荷重である.Fig. 1 に示すように粒界を摸む粒の方位をエッチピット法により求め た.ピットの観察面と粒界のなす角 $\chi$ と観察面上の粒界と線

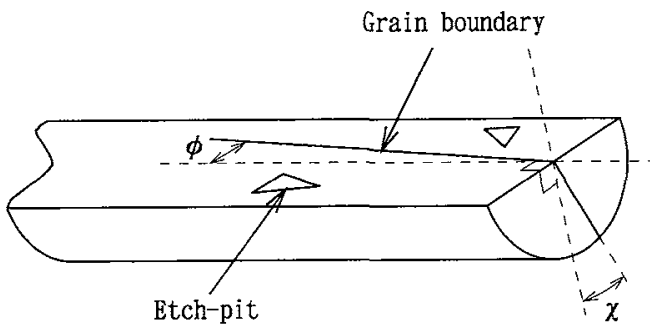

Fig. 1 Determination of the orientation of the grains by the etch-pitting technique taking two departing angles, $\phi$ and $\chi$, from the normal position of their boundary.

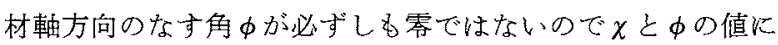
ついて補正した，その際に $\chi$ と中のどちらか一方でも $\pi / 18$ $\operatorname{rad}\left(10^{\circ}\right)$ 以上の手のは測定から除外した。 そして, 測定され た両方位から共通回転軸の方位分布叔上び Rath-Bernstein ${ }^{(4)}$ の方法による粒界性格を決定した。

引張およびクリープ試験は自動荷重一歪み制峁装置を備光た

\section{Heating rate $/ \mathrm{Ks}^{-1}$}

0. 2

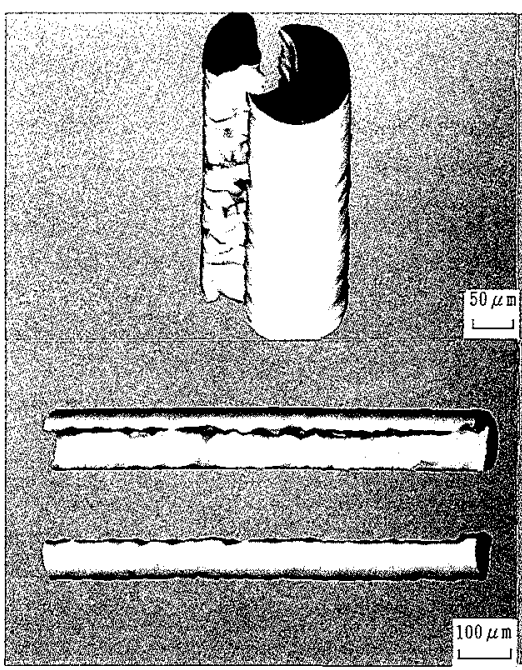

220

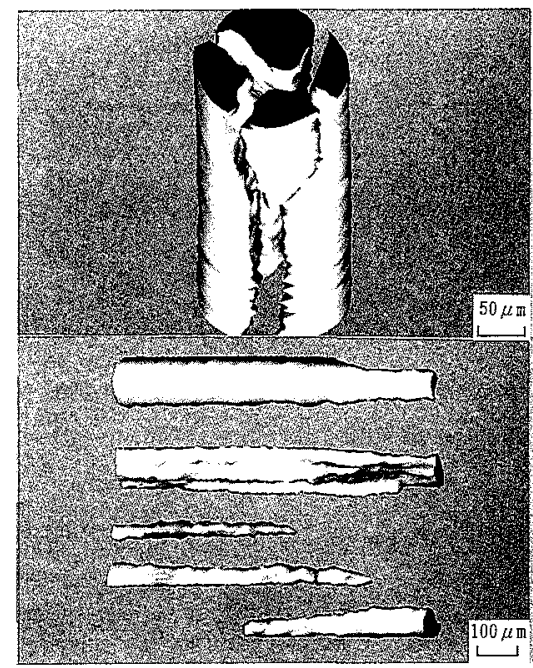

1. 7

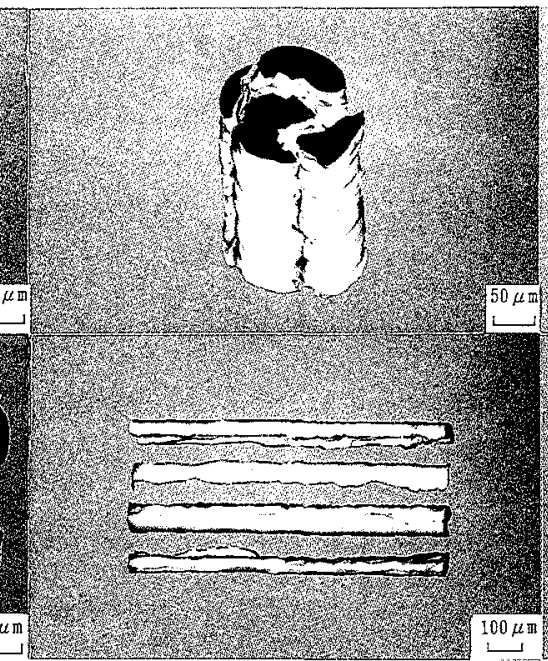

880

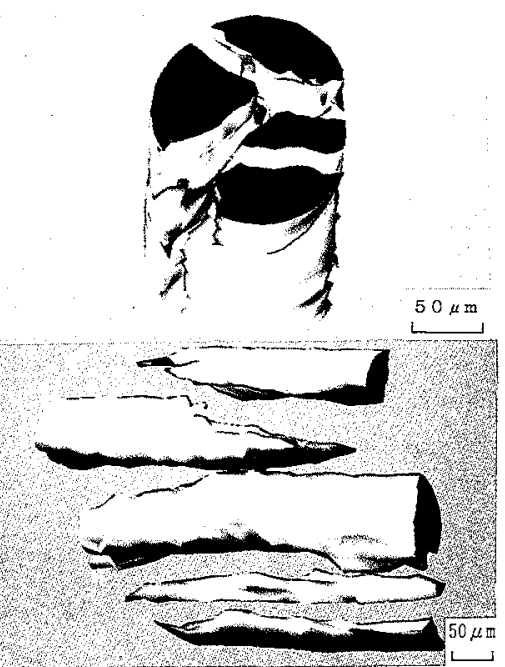

22

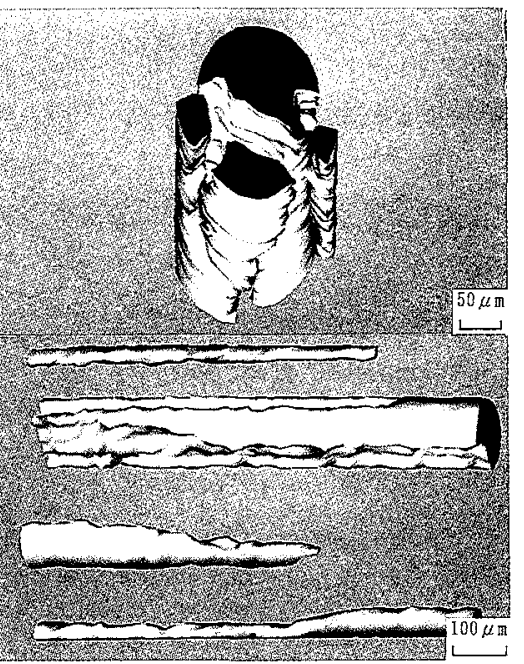

Fig. 2 Stereoscopic views of secondary recrystallized grains constructed by a threedimensional image analyzer for doped tungsten wire annealed for $300 \mathrm{~s}$ at $2273 \mathrm{~K}$ after heating at each rate. 
インストロン型引張試験機(島津製 IS-500)とよって行った. 両試験ともゲージ長さを $50 \mathrm{~mm}$ とした。試験機てセットした 試験片に通電し， $0.2 \sim 880 \mathrm{~K} / \mathrm{s}$ で昇温させ $2273 \mathrm{~K} て ゙ 300 \mathrm{~s} の$ 間保持して 2 次再結晶化させた後, 各試験を行った。引張試 験では試料を室温をで十分に冷却させて $\dot{\varepsilon}=10^{-4} \mathrm{~s}^{-1}$ の歪速度 で引張破断させて破断荷重を求めた。な拉，コイ心状火成形さ れたフィラメントは自重による㸚じり応力のためにしばしば粒 界破断することを考虑に入れて，一部の試料灶高温の状態で 試料に $\pi / 2 \operatorname{rad}\left(90^{\circ}\right)$ 称じりを加えた後に室温委で泠却させて 引張試験を行った。クリープ試験では試験温度を $2273 \mathrm{~K}$, 負 荷応力 $\sigma$ を $\sigma=28 \mathrm{MPa}$ とてて得られたりリープ曲線から定常 クリープ速度 $\dot{\varepsilon}_{\mathrm{m}}$ を求めた。直流通電加熱方式による引張変形 中の試験温度の保持, エッチピット法による結晶粒の方位測 定, 粒の3 次元的形状の測定等の方法は前報 (2)(5)(6) 飞記した 通りである。

\section{III. 実 験 結 果}

昇温速度を変化させることによって得られたインターロック の程度が異なる2次再結晶粒の形状を線材軸沿って0.5 $1.0 \mathrm{~mm}$ の長さで測定し Fig. 2 飞示す．昇温速度が増加する につれて, 粒の形状は複雑になり粒界面積が増加している、軸 方向に平行な断面上で 2 次元的に測定された粒の長さ $l$ との 幅 $w$ は，例えば昇温速度が $880 \mathrm{~K} / \mathrm{s}$ では $l=500 \mu \mathrm{m}, w=50$ $\mu \mathrm{m}$ となり(6), Fig. 2 の結果とほぼ一致しているが，昇温速度 が遅くなると粒の長さは測定の範囲をはるが超えることが分 かる、エッチピット法によって求められたこ机らの粒の軸方位 分布をFig. 3 に示す，分布の昇温速度依存性はほとんど見ら れないが，殆どのデータ点はく135〉く〈011〉の付近に分布してい る.これは变形集合組織が発達する際の結晶粒の軸方位は大部 分が〈111 $\rightarrow\langle 135\rangle \rightarrow\langle 011\rangle$ 上5に回転し，〈135〉近傍の粒が 比較的安定である(7)ことと，これらの中から1次怙よび2次 再結晶核が発生するためであると考光られる．Fig. 4 は軸方 向に測定された形状因子 $F$ の变化を昇温速度別に示したるの

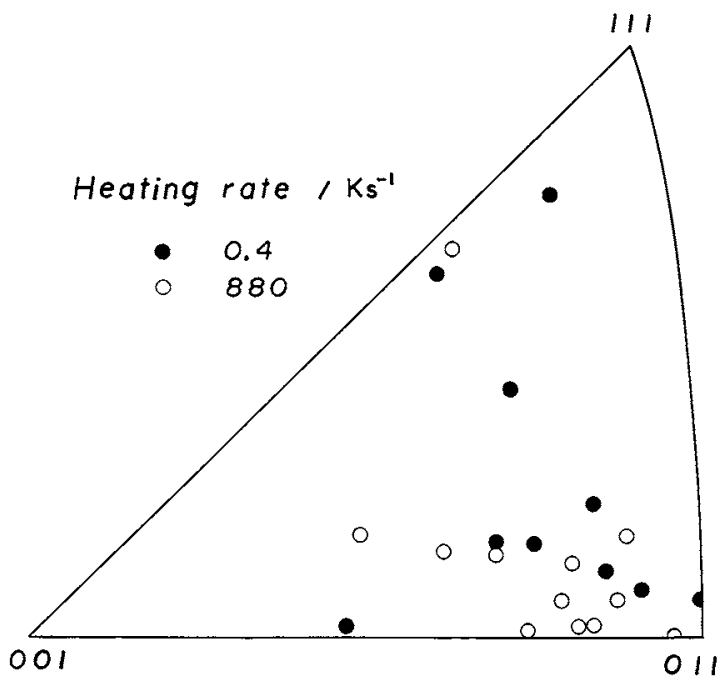

Fig. 3 Effect of heating rate on the orientations of the wire axis for the secondary recrystallized grains of doped tungsten wire.
である，昇温速度の上昇とともにFの変化が激しくなり Fig. 2 の結果と良く対応している.このような形状の変化を定量的 に把握するため前報(2) 之同様に $f_{1} \sim f_{3}$ のパラメーターを次式で 定義する。

$$
\begin{aligned}
& f_{1}=\frac{1}{N} \sum_{j=1}^{N} \frac{\sum_{i=2}^{n}\left|A_{i}-A_{i-1}\right| / \sum_{i=1}^{n} A_{i}}{n-1} \\
& f_{2}=(\bar{F})=\frac{1}{N} \sum_{j=1}^{N} \frac{\sum_{i=1}^{n} F_{i}}{n} \\
& f_{3}=\frac{1}{N} \sum_{j=1}^{N} \frac{\sum_{i=2}^{n}\left|F_{i}-F_{i-1}\right|}{n-1}
\end{aligned}
$$

ここで $N(=4 \sim 8)$ は測定された結晶粒の個数， $A_{\mathrm{i}}$ と $F_{1}$ はそれ ぞれ $i$ 番目の割断面における粒の断面積と形状因子であり, n は線材軸火沿った全割断面数で長さが500と $1000 \mu \mathrm{m}$ の測定 ではそれぞれ $n=26,51$ となる， $f_{3}$ は Fig. 4 中の，なた $f_{1}$ は $A$ の表示での折れ線の長さに比例するるのである. $f_{1} \sim f_{3}$ の昇 温速度に対する変化は Fig. 5 K示されている. $f_{1}$ と $f_{3}$ が昇温 速度の上昇以つれて添济同様の增加を示す一方， $f_{2}$ は注とんど 一定であった。

液体窒素中で圧縮袔離破断試験を行い一部の粒を破断させた

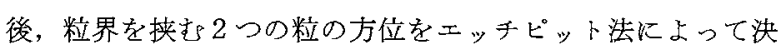
定した。これらの粒の方位から求められた共通回転軸の方位分 布をFig. 6 亿示す. Fig. 6 では軸が[001] に近付くにつれて粒 界破買を示す粒界の頻度が高くなっている. 図火おいて(a) (f) に示される半径 $\pi / 36 \mathrm{rad}\left(5^{\circ}\right)$ 以内の共通回転軸活济同一 方位であると見なして Rath-Bernstein (4)(8)の方法によって決 定した粒界性格分布をFig. 7 K示寸，破壊した粒界が傾角成 分の強い領域で見られる一方で， $\omega=\pi / 18 \operatorname{rad}\left(10^{\circ}\right)$ 以下では 粒界の形成そのものが見られない，なた，粒界が共通回転軸の

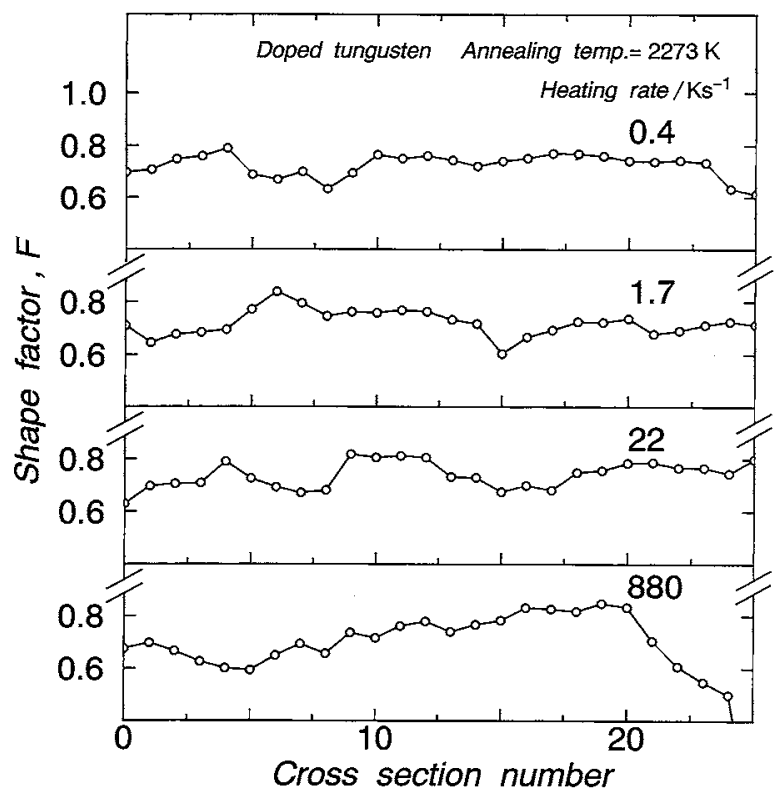

Fig. 4 Variation of the shape factor of secondary recrystallized grains with the cross section number along the wire axis for doped tungsten wire heated to $2273 \mathrm{~K}$ at each rate and annealed for $300 \mathrm{~s}$. 


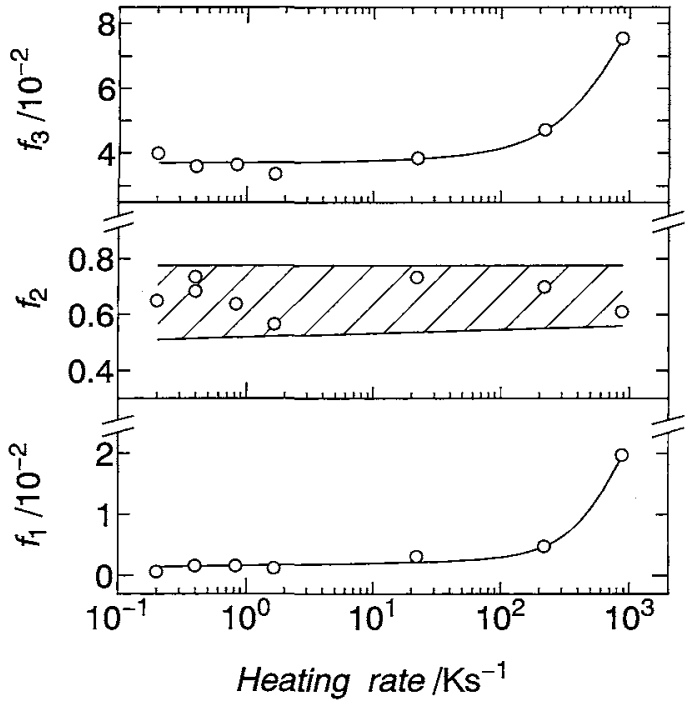

Fig. 5 Variation of the parameters, $f_{1}$ to $f_{3}$, with heating rate for doped tungsten wire heated at each rate and annealed for $300 \mathrm{~s}$ at $2273 \mathrm{~K}$.

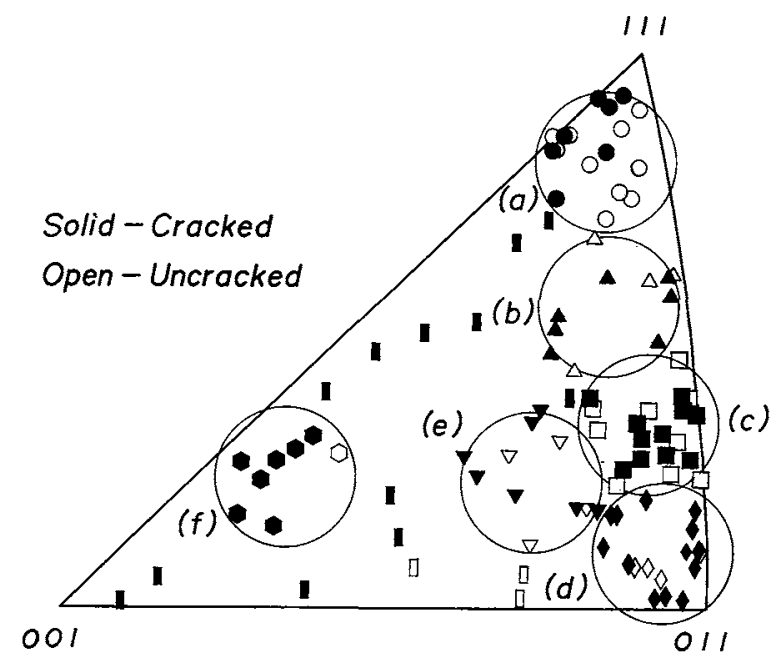

Fig. 6 Effect of orientations of the common rotation axis on the grain boundary fracture of the wire annealed for $300 \mathrm{~s}$ at $2273 \mathrm{~K}$ after heating at the rate of $0.4 \mathrm{~K} / \mathrm{s}$.

周りの回転角 $\theta$ 万向にシンダムに分布していることから，粒界 破壊が生じるか生じないかは $\theta$ 亿依存しない子思われる。

Fig. 8 は引張破断強度 $\sigma_{\mathrm{f}}$ の昇温速度依存性を示す. 図中に 示される延性の領域の (a)で性十分な延性を示してしばり切れ ているが，脆性の領域の (b)，(c)では引張時に弾性域内で破断 した.すべての $\sigma_{\mathrm{f}}$ は破断荷重を線材の初期断面積で除したも

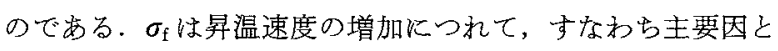

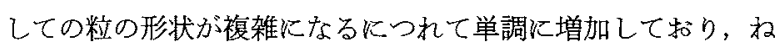
じり後の引張試験によって得られた $\sigma_{\mathrm{f}}$ る゙らつきの範囲内で これらの結果と一致した.

\section{N. 考察}

\section{1. 粒界性格と破壊}

Fig. 6 では共通回転軸が，〈011〉-〈111〉にかけて密に分布し ているが，このような分布は Fig. 3 の軸方位分布からの制約

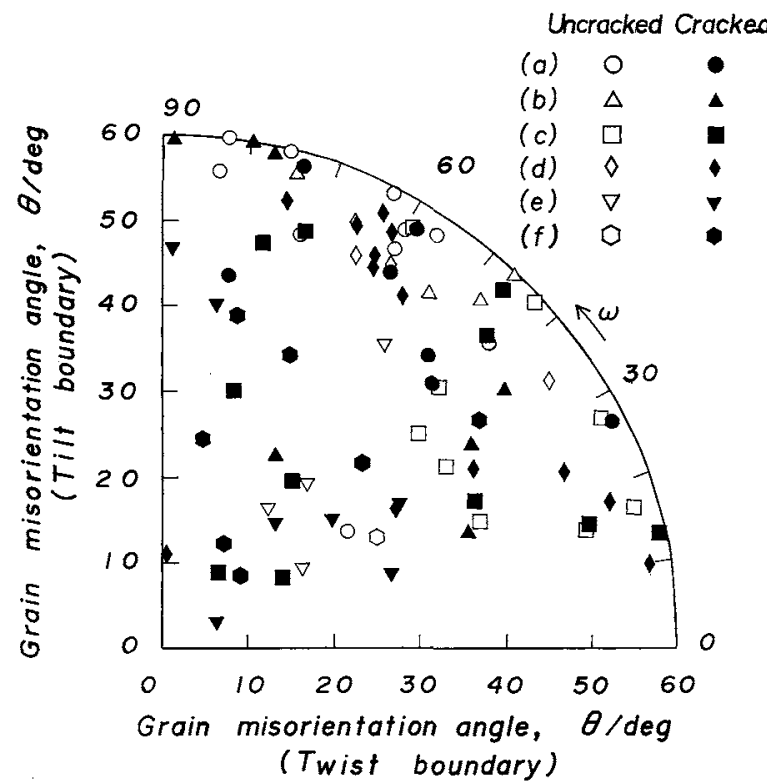

Fig. 7 Distribution of grain boundary orientations in Rath-Bernstein's expression obtained from the specimens with the common rotation axes shown in the circles (a) to (f) of Fig. 6, respectively.

を受ける結果である。また，図ではく001〉火近付くにつれて粒 界破壊を示す粒界の頻度が高くなる傾向が認められる。モリブ デンやタングステン等では軸方位がく001〉に近付くにつれて粘 界エネルギーが増加するためと思われる．Wolf ${ }^{(9)}$ は BCC 金属 の対称傾角粒界のニネルギーを計算し，Moの〈011〉と〈111〉 対称傾角粒界では，大きなカスプが生じる〈011〉の $\Sigma 3$ と $\Sigma 11$ を除いて，〈011〉の方が〈111〉よりも1〜1.2倍エネルギーが大 きいことを示している. Fig. 7 中の傾角成分が強くなる $\omega>\pi / 3 \operatorname{rad}\left(60^{\circ}\right)$ では〈011〉近傍の共通回転軸を持つ(d)のグル ープの粒界の8つの内の 7 つが粒界破懐を生じて打り，また 〈111〉近傍の共通回転軸を持つ(a)のグループの粒界では粒界 破罩を示すものの割合肪 9 個中 2 個と少ない。これは一般に 〈011〉回転軸の粒界の粒界エネルギーがく111〉回転軸と比べて 大さいためと推量される。Fig. 6,7のよらな粒界性格は昇温 速度が $0.4 \mathrm{~K} / \mathrm{s}$ と小さく, 粒の形状が単純な場合に批いて得ら れた結果である。これょりも大きな昇温速度になるとインター ロックの程度が進み, 粒界性格が激しく変化する。したがっ て，粒界珄格の制御による実用のタングステン細線の粒界破壇 の防止は不可能に近く，むしろ粒界形状による制御による方が より効果的であるように思克る。

\section{2. 耐クリープ性と粒界破壊とを改善するインターロック組 縕}

式 (1)〜 ( 3 )で定義される $f_{1} \sim f_{3}$ と粒形状との関係を模式 的に示したのが Fig.9である.（a)には $f_{3}=0$ (または $F$ が一 定)で $f_{1} か ゙ 0<f_{1}<1$ (变たは $A$ が変化する)である場合の一例 が，杰た(b)では $f_{1}=0 て ゙ 0<f_{3}<1$ の場合が示されている， $f_{1}$ $=f_{3}=0,0<f_{2}<1$ である(c) の場合飞は， $F$ の軸方向の平均值 $\left(f_{2}\right)$ が小さい時 (i ) と大きい時 (ii) とで，粒界形状には模式的 に示したような差異がある. Fig. 5 で示したように昇温速度の 増大につれて $f_{1}$ と $f_{3}$ は任とんど同様の増大を示す。これは昇 
(a)

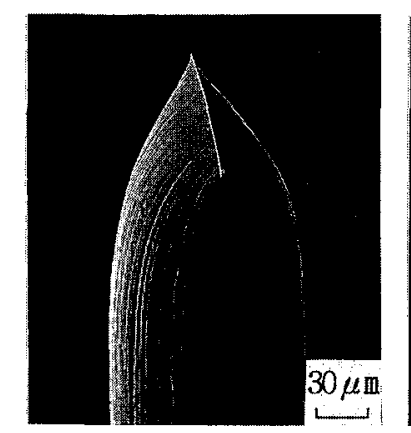

(b)

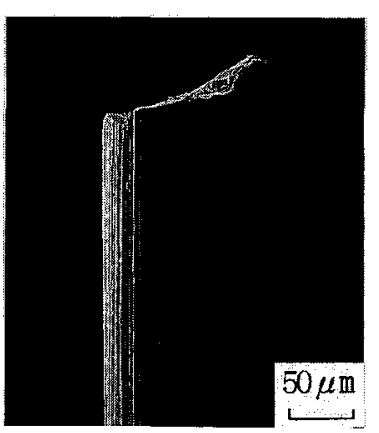

(c)

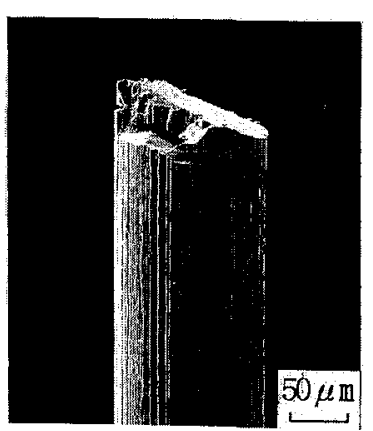

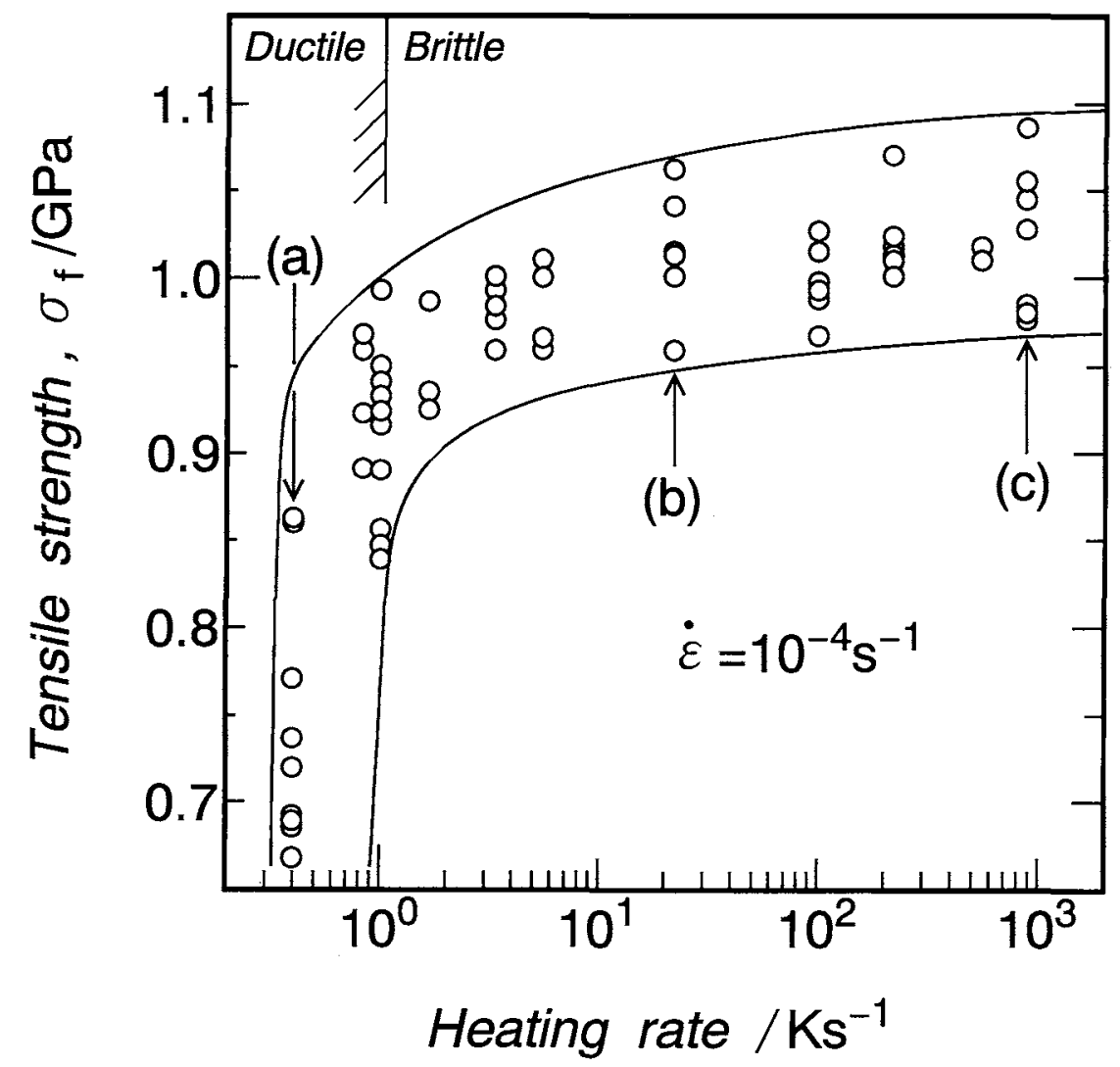

Fig. 8 Heating rate dependence of the tensile strength for doped tungsten wire tested at the nominal strain rate of $\dot{\varepsilon}=10^{-4}$ $\mathrm{s}^{-1}$ and room temperature.

温速度の増加につれて粒の断面形状は徐々に起伏を増し, 急激 な断面减少 $\left(f_{1}\right.$ の増加)が起こるような异温速度では粒の形状 が非常に複雑になることを示している。この上らにFig.5の $220 \mathrm{~K} / \mathrm{s}$ 以上で見られるように $f_{1}$ と称がともに増加する場合 には粒界の入り組み(インターロック)が激しくなり，Fig. 2 中 の $880 \mathrm{~K} / \mathrm{s}$ の粒の形状に最も良く去の特徽が現れている。李 た， $f_{1}$ と $f_{3}$ の変化に対して $f_{2}$ が泳㜔一定であるといらことは 各断面に和ける形状は，㴗㴗一定で昇温速度によっては大きく 壮变化しないことを意味して括う，Fig. 2 の各断面の形状から も明らかで岗るとこでインターロックの程度を表すパラメー ターとして $f_{1}$ と $f_{3}$ の積 $f_{1} \cdot f_{3}$ 定義し, 异温速度を介して定 常クリープ速度 $\dot{\varepsilon}_{\mathrm{m}}$ と粒界面積 $S / V$ との関係を調べたのが Fig. 10 である゙.
†ここで図中には $2273 \mathrm{~K}$ 以外の焼鈍温度の粒の測定結果に ついても参考まで火示されている. また，S/VはFig. 2 に示されるよらに昇温速度が遅くなると測定範囲 $L$ $(=500 \sim 1000 \mu \mathrm{m})$ が実際の粒の長さより短くなるため過 小評価される。そこで粒を長さが $l_{\mathrm{t}}$ で直径が $w_{\mathrm{t}}$ の円筒で 近似すれば $S / V$ 亿両端の断面積 $\left(\pi w_{\mathrm{t}}^{2} / 2\right)$ が含をれる長さ にあで測定が理想的に行われた場合 $\left(L \simeq l_{\mathrm{f}}\right)$ と断面積が含 まれないで測定の長さが不十分である場合 $\left(L<l_{\mathrm{t}}\right)$ の差, すなわら粒 1 個见ついての過小評価量は $\left(\pi w_{\mathrm{t}}^{2} / 2\right)\left(1-L / l_{\mathrm{t}}\right)$ となるので，線材の直径を $d$ とすれば断面に含まれる $(d /$ $\left.w_{\mathrm{t}}\right)^{2}$ 個の粒では過小評価量 $\Delta S / V$ は $\Delta S / V=\pi d^{2}\left(l_{\mathrm{t}}-L\right) /$ $2 l_{\mathrm{t}}$ となる。 $d=0.13 \mathrm{~mm}, l_{\mathrm{t}} \simeq l$ と $w_{\mathrm{t}}=w /(2 / 3)^{1 / 2}$ の関保和 よび 2 次元的な測定から求められる $l$ を を計算し，図中 $2273 \mathrm{~K} の S / V$ は $\Delta S / V$ を含をように補 正されている.しかし， $\Delta S / S\left(=\Delta S V^{-1} / S V^{-1}\right)$ は約 $15 \%$ 以下と小さく，上の上らな補正を施していない他の温度で のデータとの関係にも大きな影響は与えていない。 
(a) $0<f_{1}<1$ at $f_{3}=0$

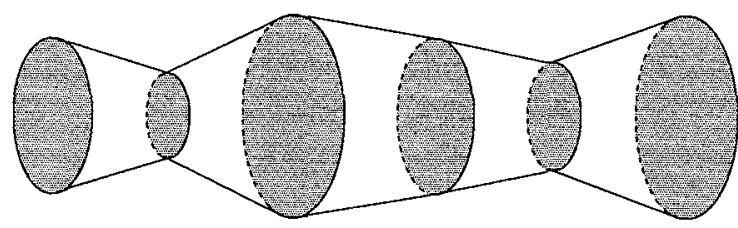

(b) $0<f_{3}<1$ at $f_{1}=0$

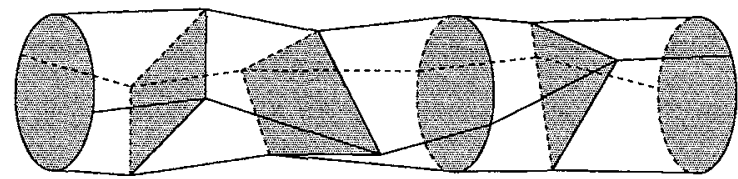

(c) $f_{1}=f_{3}=0$

(i) $\operatorname{small} f_{2}$

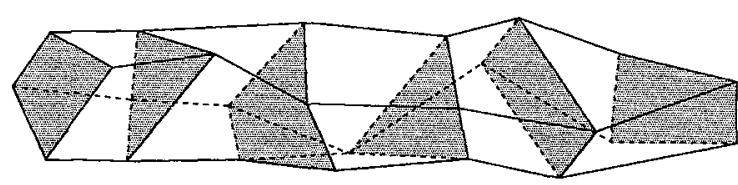

(ii) 1 a rge $f_{2}$

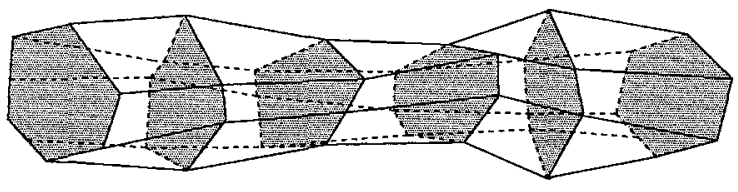

Fig. 9 Schematic representation of the characteristic change of grain morphologies in the cases of (a) $0<f_{1}<1$ at $f_{3}=0$, (b) $0<f_{3}<1$ at $f_{1}=0$ and (c) $f_{2}$ having (i) small and (ii) large values within the range of $0<f_{2}<1$ at $f_{1}=f_{3}$ $=0$.

いずれの焠鈍温度です昇温速度が増し $f_{1} \cdot f_{3}$ が增加するとS/ $V$ す增加するが，昇温速度や焼鈍温度は $S / V$ と $f_{1} \cdot f_{3}$ を一義 的に関係づける一因子炕すぎない，S/Vが大きくならない組 織では $f_{1} \cdot f_{3}$ は $\dot{\varepsilon}_{\mathrm{m}}$ 詨して負に寄与し, 粒の形状によるクリ ープ速度の抑制効果(2)(10)が認められる。しかし，S/Vが大き くなると粹界すべりや粒界キャビテーション(3)のような粒界の 存在そのものに起因するクリープのために $\dot{\varepsilon}_{\mathrm{m}}$ が再び堌加する ことが分かるこのように $\dot{\varepsilon}_{\mathrm{m}}$ が粒の形状(組織)の影響を受け ながら変化する様子を模式的に示したのが Fig. 11 である. $\dot{\varepsilon}_{\text {m }}$ は主に粒界面積によって支配される領域と粒界形状によって支 配される2つの領域に分けられ，いずれの領域に拈いても

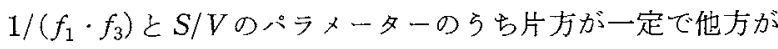
増加するにつ机て $\dot{\varepsilon}_{\mathrm{m}}$ は増加するような曲面を形成する。攵し て， $\dot{\varepsilon}_{\mathrm{m}}$ は昇温速度の変化に対しては底面上の破線で示される よ5に $1 /\left(f_{1} \cdot f_{3}\right) \subset S / V か ゙$ 反比例的な関係を保ちながら变化 する(2)ため, 兩領域の境界において最小值をとる。一方, 室温 での $\sigma_{\mathrm{f}}$ は昇温速度の増加とともに単調に増加する(Fig. 8参 照)ので， $\dot{\varepsilon}_{\mathrm{m}}$ が最小に近い範团でかつ原が小さくならないよ らな最適条件を決定することができる。ここで，Fig. 11 の底

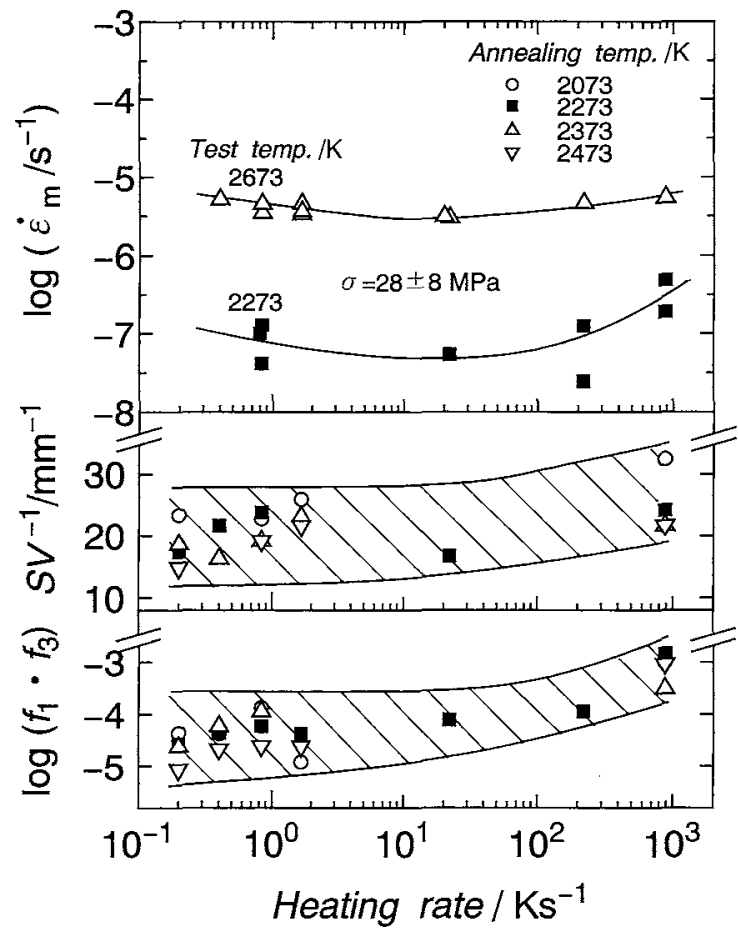

Fig. 10 Heating rate and annealing temperature dependence of $f_{1} \cdot f_{3}, S / V$ and $\dot{\varepsilon}_{\mathrm{m}}$.

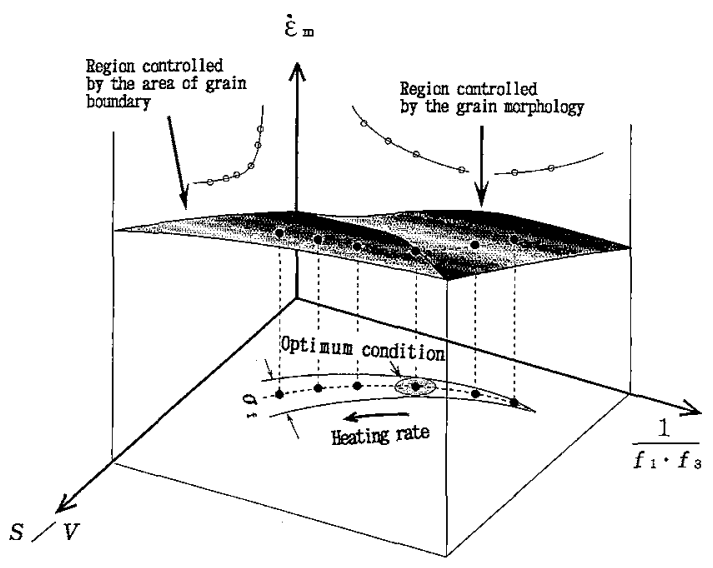

Fig. 11 Schematic representation of the relation between $1 /\left(f_{1} \cdot f_{3}\right), S / V$ and $\dot{\varepsilon}_{\mathrm{m}}$.

面に与えられる $S / V$ と $f_{1} \cdot f_{3}$ の関係は昇温速度と焼鈍温度に よって一義的に与兄られるが, それに対する $\dot{\varepsilon}_{\mathrm{m}}$ は温度, 応 力, 組織化依存するので図中の 2 つの曲面の形状山変形条件 によって変化する. 同一組織沈対する $\dot{\varepsilon}_{\mathrm{m}}$, 温度, 応力の互い の関係は変形機構図によって知ることがでさ, 例光ば0.83と $880 \mathrm{~K} / \mathrm{s}$ の昇温速度で昇温し $2373 \mathrm{~K} て ゙ 300 \mathrm{~s}$ 間燒鈍された試 料汇対する変形機構図 ${ }^{(5)}$ は Fig. 12 と13にそれぞれ示される. 剪断応力を $\tau(=\sigma / 2)$ として図中に示される $\sigma=28 \pm 8 \mathrm{MPa} て ゙$

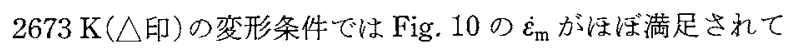
いることが分かる。 


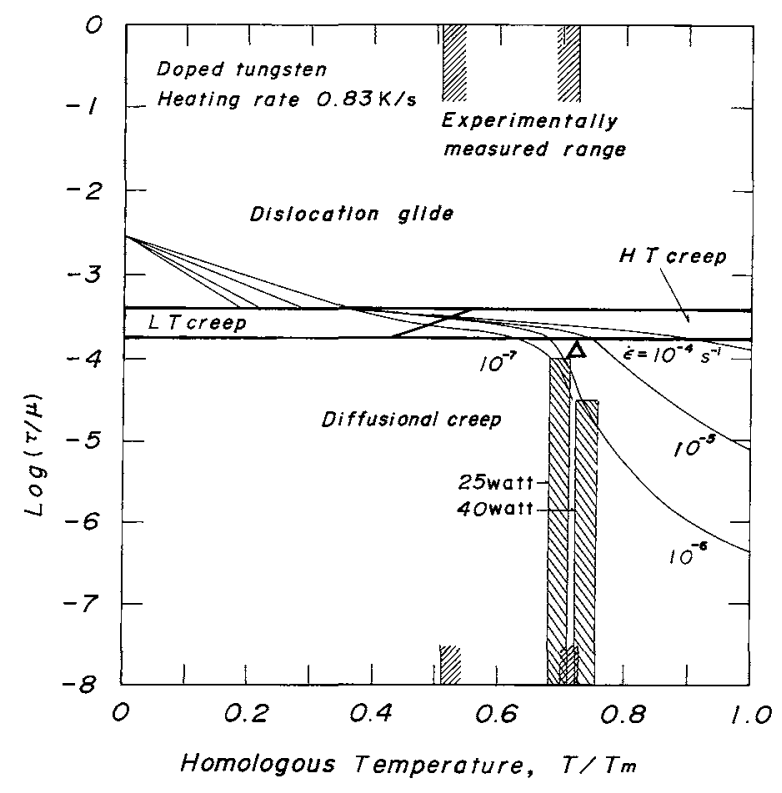

Fig. 12 Deformation mechanism map for doped tungsten wire heated at $0.83 \mathrm{~K} / \mathrm{s}$ and annealed for $300 \mathrm{~s}$ at $2373 \mathrm{~K}$. The mark of $\triangle$ indicates the testing condition of $\sigma=28$ $\mathrm{MPa}$ and $2673 \mathrm{~K}$.

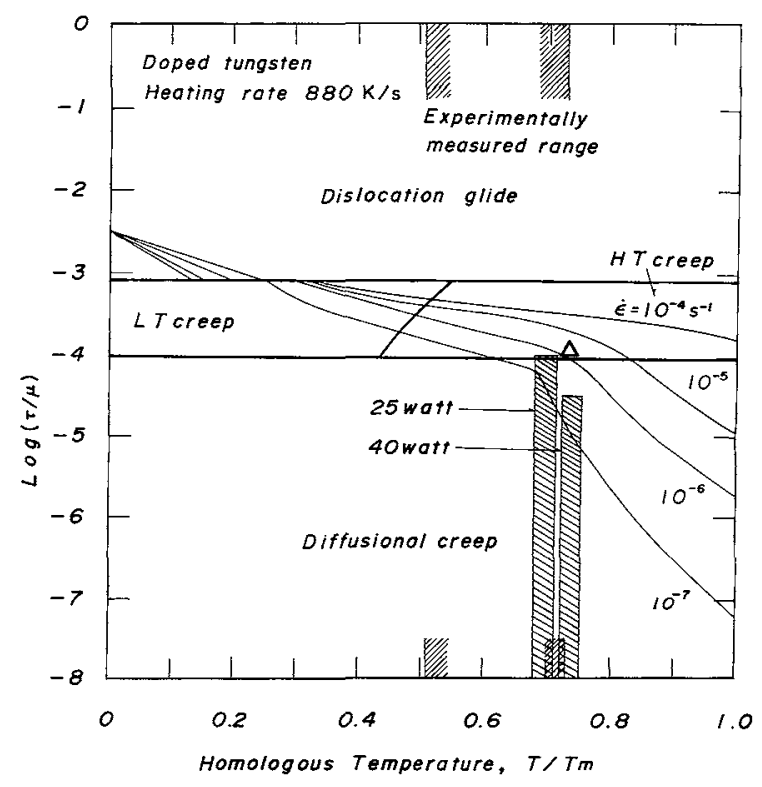

Fig. 13 Deformation mechanism map for doped tungsten wire heated at $880 \mathrm{~K} / \mathrm{s}$ and annealed for $300 \mathrm{~s}$ at $2373 \mathrm{~K}$. The mark of $\triangle$ indicates the testing condition of $\sigma=28$ $\mathrm{MPa}$ and $2673 \mathrm{~K}$.

コイル状に成形されている実際のフィラメントの断面には自 重に上るねじり応力がかかり，白熱球が通常 $3.6 \times 10^{6} \mathrm{~s}$ 以上 の耐用寿命を详成するためにはクリープ速度は $\dot{\varepsilon}_{\mathrm{m}}<10^{-9} \mathrm{~s}^{-1}$ でなければならない(11)ので，その使用は図示される範团内に
制限される。このように実際にはさらに低いねじり応力でする のに加充て粒形状のクリープに対する抑止效果 ${ }^{(2)(10)}$ が重要な 役割をはたす、したがって，ねじり応力に関する $\dot{\varepsilon}_{\mathrm{m}}$ の等高線 は高応力側へ移動する(11) あのと考光られる．以上のことから 結論として，昇温速度と焼鈍温度とを適当に組合孔ることに上 $\eta ， \dot{\varepsilon}_{\mathrm{m}}<10^{-9} \mathrm{~s}^{-1}$ 容易に満足し，消灯時の粒界破壊をむ防 止することができると考京られる。

\section{V. 結 論}

タングステン白熱球フィラメント材に执ける耐クリープ性の 向上と粒界破懐防止といら相反する2つの役割を满足する最 適なインターロック組織を明らかたするため，2 次再結晶粒の 粒界性格と粒界破壊との相関，インターロックの程度を示すパ ラメーターと定常クリープ速度ならびに引張破断強度との関係 を調べた。以下に得られた結果を要約する。

(1) インターロックの程度を示すパラメーターとして定義し た $f_{1} \cdot f_{3}$ は 3 次元的に測定された粒の形状の変化の特徵を良 く表打。

（2）粒界を挟も2 結晶粒の共通回転軸の方位分布は方位が 〈001〉に近付くにつ礼て粗になり，同時に粒界破壊を示す粒界 の頻度が高くなる。

（3） 2 次再結晶粒の粒界は侸とんどが湜合粒界で，その破壊 の頻度は共通回転軸の周りの回転角とは無関係に傾角成分が増 加するにつれて増加する傾向が市る。

（4）粒界面積があまり大きくならないよらな昇温速度の範囲 (組織)ではインターロックの程度が増加するにつれてクリープ 速度を捛制する粒界形状の効果が認められる，一方，粒界面積 が大きくなると粒界の存在去のものに起因する粒界すべりと粒 界キャビテーション等のためにクリープ速度が堌加する．室温 での引張破断强度はインターロックの進行とともに単調《増加 するのでクリープ速度を最小限に押さえかつ破断強度があまり 低下しないよらな最適な組織を決定することができる。

\section{文献}

（1）田上耕司, 岡田道治, 松田日出彦: 日本金属学会誌, $\mathbf{5 8 ( 1 9 9 4 ) , 1 1 0 3 .}$

（2）田上耕司，桜井裕士，藤井浩二，松田日出彦：日本金属 学会誌, 57(1993), 14 .

(3) K. Tanoue, Y. Ohtani and H. Matsuda: Mater. Trans., JIM, 34 (1993), 1177.

(4) B. B. Rath and I. M. Bernstein: Met. Trans., 2(1971), 2845 .

（5）田上耕司, 米田博之, 藤井浩二, 松田日出彦：日本金属 学会誌, 54(1990), 991 .

（6）陳樹繁，米田博之，藤井浩二，田上耕司，松田 日出彦：日本金属学会誌，53(1989), 1198.

(7) I. L. Dillamore and H. Katoh: Met. Sci., 8(1974), 73

（8）田上耕司, 有井初志, 甲斐安直, 松田日出章: 日本金属 学会誌, 51(1987), 1003 .

(9) D. Wolf: Phil. Mag., 62(1990), 447

(10) R. Raj and M. F. Ashby: Met. Trans., 2(1971), 1113

(11) H. J. Frost and M. F. Ashby: Rate Processes in Plastic Deformation of Materials, Ed. by J. C. M. Li and A. K. Mukherjee, ASM, (1975), 70. 